\title{
Investigation of gaseous emissions and ash deposition in a pilot-scale PF combustor co-firing cereal co-product biomass with coal
}

\author{
Ala Khodier, Nigel Simms, Paul Kilgallon and Nigel Legrave \\ Energy Technology Centre, School of Applied Sciences, Cranfield University \\ Cranfield, Bedfordshire MK43 0AL, England, UK \\ Phone: +44 (0) 1234 750111, e-mail: a.khodier@cranfield.ac.uk, n.j.simms@cranfield.ac.uk, \\ p.j.kilgallon@cranfield.ac.uk, n.a.legrave@cranfield.ac.uk.
}

\begin{abstract}
This study presents the results of investigations into the gaseous emissions and ash deposition characteristics from combustion of Cereal Co-product mixed with coal in a $100 \mathrm{~kW}_{\text {th }}$ pulverised fuel combustor. Combustion gas emission samples for $\mathrm{CO}_{2}, \mathrm{O}_{2}, \mathrm{H}_{2} \mathrm{O}, \mathrm{SO}_{2}, \mathrm{CO}, \mathrm{NO}, \mathrm{NO}_{2}, \mathrm{~N}_{2} \mathrm{O}, \mathrm{HCl}, \mathrm{HF}$, were obtained on-line by a high resolution multi-component Fourier Transform Infra-Red gas analyser. Ash deposit samples were collected from the flue gas using three air-cooled probes that simulate heat exchanger tubes with surface temperatures of 500,600 and $700{ }^{\circ} \mathrm{C}$. The deposits formed were analysed using $\mathrm{SEM} / \mathrm{EDX}$ and $\mathrm{XRD}$ techniques to assess their corrosion potential.
\end{abstract}

\section{Key words}

Biomass, Co-firing, Emissions, Ash Deposition, Pulverised Fuel Combustion.

\section{Introduction}

The UK government enacted the Renewable Obligation (RO) on $1^{\text {st }}$ April 2002 (and effective until $31^{\text {st }}$ March 2027) to reduce $\mathrm{CO}_{2}$ emissions via encouraging the growth of renewable energy sources such as biomass, wind, solar, geothermal and hydrogen for electricity generation. It set a challenging target of reducing $\mathrm{CO}_{2}$ emissions by $60 \%$ by 2050 with real progress by 2020 [1].

Recent studies in United States and Europe have demonstrated that for electric utilities producers, cofiring biomass with coal is among the less expensive alternatives for $\mathrm{CO}_{2}$ emission reduction [2, 3]. This reduction in net $\mathrm{CO}_{2}$ emissions by the addition of biomass fuels can be applied to most existing coal-fired power plants. Additional benefits, such as increasing use of local resources and decreasing demand for disposal of residues, can also be achieved.

One of the crucial concerns when considering biomass co-firing is the availability of sufficient biomass to warrant undertaking plant modifications. Of the available potential fuels, wood and straw based products are distinct types that are available in large quantities.

When compared with coal compositions, biomass in general is characterised as having a higher volatile matter content, lower heating values, less carbon, more oxygen, higher moisture content, usually lower density, wider size distribution and more volatile alkali content. This causes co-firing technology to face some critical issues, such as operating performance, flame stability, heat exchanger disturbances, ash deposition, combustor slagging, fouling and/or corrosion.

In biomass and coal fuel blends, the alkali metals sodium $(\mathrm{Na})$ and potassium $(\mathrm{K})$ play an important role in ash deposit formation, deposit thickness and ash melting point. They react with chlorine from the fuel to form volatile species (e.g. $\mathrm{NaCl}$ and $\mathrm{KCl}$ ) in the hot flue gases, which are capable of condensing onto cooler metal surfaces, such as heat exchangers, as chloride salt deposits. They can also react with sulphur in the fuel and/or with $\mathrm{SO}_{2}, \mathrm{SO}_{3}$ gas species as a vapour and/or condense during co-firing to produce sulphate salts $\mathrm{Na}_{2} \mathrm{SO}_{4}$ and $\mathrm{K}_{2} \mathrm{SO}_{4}[4]$.

The gaseous emissions of primary concern from the combustion and co-combustion of biomass and coal in power plant systems are $\mathrm{CO}_{2}, \mathrm{SOx}, \mathrm{NOx}\left(\mathrm{NO}\right.$ and $\left.\mathrm{NO}_{2}\right)$, $\mathrm{N}_{2} \mathrm{O}$, CO, particulate (fly ash), acid halides (e.g. $\mathrm{HBr}$, $\mathrm{HCl}, \mathrm{HF}$ ), the organic compounds (such as VOCs, PAHs, chlorinated dioxins (PCDD), furans (PCDF)) and trace metals [4]. The sulphur and nitrogen contents of any fuel and/or the relative amounts of each fuel in the mixture influences the co-firing emissions. The SOx emissions are directly related to the sulphur content of fuels, but NOx emissions levels depend on the combustion temperature as well as the fuel composition $[4,5]$. Thus it is more difficult to predict the effect of co-firing on NOx.

There is a recent trend in increasing utilisation of biomass in industrial and utility boilers for environmental benefit but there is little data on the gas emissions and 
ash deposition in high share ( $\geq 20 \%$, wt) biomass-coal fired combustion system. Investigations of emissions characteristics and ash deposition are required to maximise the efficiency and reliability of boiler plant. In this work, straw based Cereal Co-product (CCP) biomass mixed with coal was combusted in $100 \mathrm{~kW}_{\text {th }}$ pilot-scale combustion test rig. The flue gas emissions and ash deposition resulting from the combustion of a range of fuel blends were investigated.

\section{Experimental}

\section{A. Fuels compositions}

The compositions of the El-cerrejon coal and Cereal Coproduct biomass (CCP) used in this study were provided by E. ON Engineering plc [Power Technology Centre, Ratcliffe-on-Soar, Nottingham, UK]. Their compositions in terms of the major elements $(\mathrm{C}, \mathrm{H}, \mathrm{O}, \mathrm{N}, \mathrm{S}, \mathrm{Cl})$ are given in Table 1, whereas their ashed compositions are given in Table 2. Using these ashed compositions, the amount of the minor elements ( $\mathrm{Si}, \mathrm{Al}, \mathrm{Fe}, \mathrm{Ca}, \mathrm{Mg}, \mathrm{K}, \mathrm{Na}$, $\mathrm{Ti}, \mathrm{Ba}, \mathrm{Mn}, \mathrm{P}$ ) in moles/kg unit of each fuel and the blend mixtures were calculated.

Table 1. Composition (\% wt, of major elements on as received (AR) basis) of fuels considered in the study

\begin{tabular}{|c|c|c|c|c|c|c|c|c|}
\hline Fuel & Moisture & Ash & C & H & O & N & S & Cl \\
\hline & \%wt AR & \%wt AR & \%wt AR & $\%$ wt AR & \%wt AR & \%wt AR & $\%$ wt AR & \%wt AR \\
\hline El -Cerrejon coal & 5.80 & 8.60 & 69.20 & 4.40 & 9.98 & 1.42 & 0.58 & 0.02 \\
\hline Cereal Co-product (CCP) & 8.10 & 4.20 & 43.30 & 5.80 & 35.57 & 2.70 & 0.16 & 0.17 \\
\hline
\end{tabular}

Table 2. Ash composition (\% wt, (ash)) of fuels

\begin{tabular}{|l|c|c|c|c|c|c|c|c|c|c|c|c|}
\hline Fuel & $\mathbf{S i O}_{2}$ & $\mathbf{A l}_{2} \mathbf{O}_{3}$ & $\mathbf{F e}_{2} \mathbf{O}_{3}$ & $\mathbf{C a O}$ & $\mathbf{M g O}$ & $\mathbf{K}_{2} \mathbf{O}$ & $\mathbf{N a}_{2} \mathbf{O}$ & $\mathbf{T i O}_{2}$ & $\mathbf{B a O}$ & $\mathbf{M n}_{3} \mathbf{O}_{4}$ & $\mathbf{P}_{2} \mathbf{O}_{\mathbf{5}}$ \\
\hline & \multicolumn{9}{|c|}{$\%$ wt (of total ash) } \\
\hline El-cerrejon coal & 60.69 & 22.01 & 7.43 & 2.27 & 2.90 & 2.32 & 1.06 & 0.92 & 0.11 & 0.06 & 0.21 \\
\hline Cereal Co-product (CCP) & 44.36 & 2.79 & 2.47 & 7.78 & 3.96 & 24.72 & 0.36 & 0.12 & 0.05 & 0.10 & 12.04 \\
\hline
\end{tabular}

\section{B. Combustion Rig and emissions analysis}

A pilot-scale pulverised fuel (PF) combustor with $~ 12$ $15 \mathrm{~kg} / \mathrm{hr}$ feed rate (based at Cranfield University) was used for this study. Figure 1 shows the layout of combustion rig. The rig consisted of a main combustion chamber with fuels fed from the top. Air was pre-heated by a gas burner and then passed into the main combustion chamber burner. The flue gases leaving the combustor pass through a water cooled heat exchanger assembly before entering a cyclone and then going through an extraction fan and exiting through the stack. Gas and rig temperatures were measured throughout the hot gas path. Combustion gas emission samples for $\mathrm{CO}_{2}, \mathrm{O}_{2}, \mathrm{H}_{2} \mathrm{O}$, $\mathrm{SO}_{2}, \mathrm{CO}, \mathrm{NO}, \mathrm{NO}_{2}, \mathrm{~N}_{2} \mathrm{O}, \mathrm{HCl}, \mathrm{HF}$ were obtained from a sampling port located at the side-access of the rig and analysed by on-line high resolution multi-component Fourier Transform Infra-Red (FTIR) gas analyser. Ash was collected using three cooled deposit probes. These probes had two stainless steel rings and a removable ceramic ring $(\mathrm{OD}=39.05 \mathrm{~mm}, \mathrm{ID}=32.16 \mathrm{~mm}$, length $=$ $60 \mathrm{~mm}$ ) on which the deposits were collected. Scanning Electron Microscope (SEM) and X-ray Diffraction
(XRD) analyses were then used to analyse the deposit compositions.

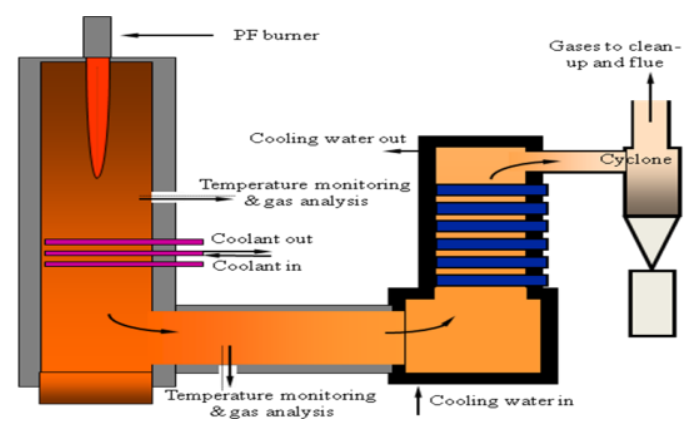

Fig. 1. Schematic diagram of the PF combustion facility

\section{Feeding system}

The pulverised feeding system consisted of a fuel hopper attached to shaker device (with speed controller), stainless steel high flow vacuum pump for material transfer and a tube feeding line leading to the combustor. Figure 2 shows a schematic diagram of the feeding system. The principle of operation of the vacuum pump unit is that nitrogen is fed into an outer annular ring that has a number of orifices leading into the centre of the unit. There, the nitrogen flow rotates with a spiral motion (similar to a corkscrew) creates a powerful vacuum flow (i.e. cyclonic flow) capable of drawing materials into through, and out of the pump under force. The fuels hopper has a capacity of $\sim 7 \mathrm{~kg}$ (fuel loading) and is placed on the shaker unit in a vertical position. The shaker unit is used to agitate the fuels to prevent slumping, bridging and agglomeration of the materials. Also, it can vibrate the fuels at various speed which can increase or decrease the fuel feeding rate injected to the vacuum pump unit and hence to the combustor chamber.

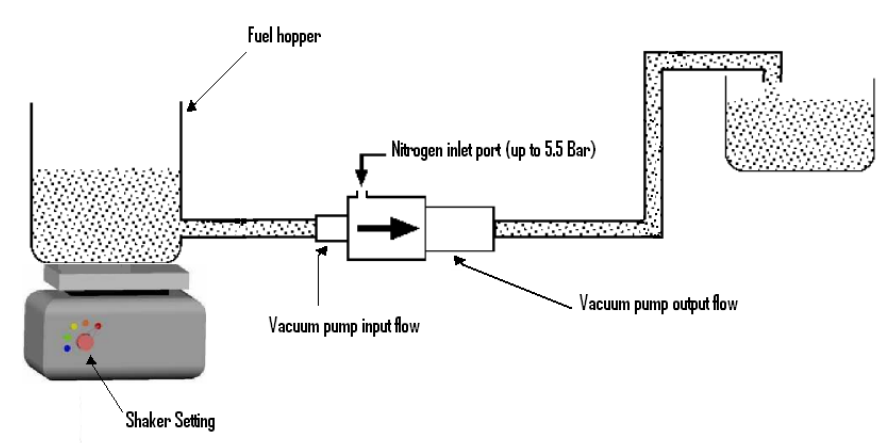

Fig. 2. Schematic diagram of the PF feeding system

\section{Combustion conditions}

Before each run, the natural gas-fired pilot burners, compressed air, cooling water system and exhaust fan were first put into operation for about 18 hours. This helped to raise the combustor chamber temperature to above $800{ }^{\circ} \mathrm{C}$. Also, the combustor was run at negative pressure to prevent the gases escaping into the combustion hall. The PF fuels were sieved to $2 \mathrm{~mm}$ size (average size of $0.5 \mathrm{~mm}$ ) particles and a consistent 
feeding rate was applied during the run. Fuel mixtures were prepared by mixing the appropriate amount of each in a bucket. About $6.5 \mathrm{~kg}$ of fuel was initially placed in the feed hopper for each experiment and refills of materials were applied during the run.

Combustion conditions such as air flow, natural gas flow, deposit probes temperatures, solid feed rate were recorded throughout the operating run. Table 3 lists the operational conditions used in this test work.

Table 3. Combustion operating conditions

\begin{tabular}{l|c}
\hline Feeding & \\
\hline $\begin{array}{l}\text { Solid feeding rate, } \mathrm{kg} / \mathrm{hr} \\
\text { Feeding } \mathrm{N}_{2} \text { flow rate, } \mathrm{L} / \mathrm{min}\end{array}$ & 30 \\
& \\
Pilot-scale combustion & \\
Natural gas flow rate, $\mathrm{L} / \mathrm{min}$ & 40 \\
Combustor air flow rate, $\mathrm{L} / \mathrm{min}$ & 1730 \\
$\begin{array}{l}\text { Water flow rate, } \mathrm{L} / \mathrm{min} \\
\text { Combustor chamber gas temp. at } \\
\text { deposition probes, }{ }^{\circ} \mathrm{C}\end{array}$ & 50 \\
Pre-heated air temperature, ${ }^{\circ} \mathrm{C}$ & $\sim 820-850$ \\
$\begin{array}{l}\text { Average deposit probes exhaust } \\
\text { temperature, }{ }^{\circ} \mathrm{C}\end{array}$ & 350 \\
\end{tabular}

\section{Results and Discussions}

\section{A. Combustion efficiency and gaseous emissions}

Constant fuel feed rates of about 7.5, 9.2, 7.9, 8.5, 9.0 and $9.6 \mathrm{~kg} / \mathrm{hr}$ were applied for El-cerrejon coal (100\%, wt), CCP biomass (100\%,wt) and mixed fuel (CCP:Elcerrejon coal, 20:80 \%, wt), (CCP:El-cerrejon coal, 40:60 $\%$, wt), (CCP:El-cerrejon coal, 60:40 \%, wt), (CCP:Elcerrejon coal, 80:20 \%, wt) combustion test runs, respectively. Figure 3 shows the major flue gas components produced and Figure 4 the minor gaseous species during two hours of stable combustion of three of these fuels (as examples).

Low CO emissions were achieved for all mixed fuel combustion. For example, $\mathrm{CO}$ emissions with averages of 324, 232 and $152 \mathrm{ppm}$ for El-cerrejon coal (100\%, wt), CCP biomass (100\%, wt) and CCP:El-cerrejon coal (80:20\%,wt), respectively (Fig. 4), imply that most of the burnt carbon was converted to $\mathrm{CO}_{2}$ (i.e. high combustion efficiency). This result would be expected from pulverised coal combustion, but is a significant data record for a high blend mixture of biomass (i.e. $80 \%$, wt) with coal.

Pilot-scale combustion gave the compositions of the major flue gases for El-cerrejon coal $(100 \%$, wt) with an average of $9.2 \% \mathrm{CO}_{2}, 13.3 \% \mathrm{H}_{2} \mathrm{O}, \mathrm{CCP}(100 \%$, wt) with an average of $11.6 \% \mathrm{CO}_{2}, 13.4 \% \mathrm{H}_{2} \mathrm{O}$ (Fig. 3). For the mixed fuel combustion (CCP:El-cerrejon coal, 80:20 $\%$, wt), the flue gas compositions resulted an average of $11.5 \% \mathrm{CO}_{2}$ and $14.3 \% \mathrm{H}_{2} \mathrm{O}$. The $\mathrm{CO}_{2}$ volume outcomes of the experimental study match closely with the mass balance calculations of El-cerrejon coal (12.0\%), CCP (11.6\% $\mathrm{CO}_{2}$ ) and CCP:El-cerrejon coal mixtures $(11.7 \%$
$\mathrm{CO}_{2}$ ). The $\mathrm{H}_{2} \mathrm{O}$ volume outcomes of the experimental study showed a variations with the mass balance calculations which were 8.6, 12.9 and $11.7 \% \mathrm{H}_{2} \mathrm{O}$ for Elcerrejon coal, CCP and CCP:El-cerrejon coal mixtures, respectively. Conceptually the cause is mass balance calculations were adopted to have the percent volumes of oxygen output of $4.0 \%$. Whereas, the oxygen output of the experimental combustion study of El-cerrejon coal, CCP and CCP:El-cerrejon coal mixtures (80:20\%, wt) were in the range of 5-9, 6-8, 3.9-7 \%, respectively. Also, other factors, such as fuel moisture content could have changed during storage, proper mixing of solid fuels particles, residence time, combustion zone temperature, type of feeding and the cooling effects of excess air should also be taken into consideration [4].
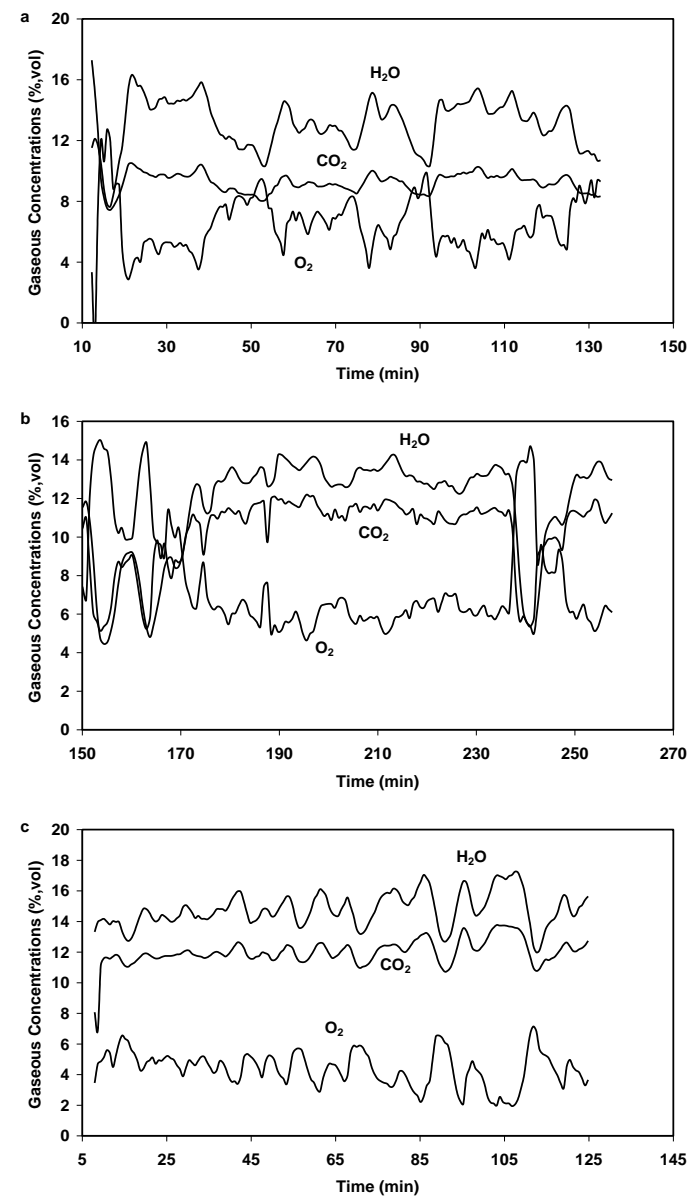

Fig. 3. Major species emissions from combustion of a) Elcerrejon coal $(100 \%$, wt), b) CCP $(100 \%$, wt) and c) CCP:Elcerrejon $(80: 20 \%, \mathrm{wt})$.

Examining the minor gaseous species $\mathrm{SO}_{2}$ indicates that the $\mathrm{SO}_{2}$ concentration is high in El-cerrejon coal (range of 396-452 ppm) compared with CCP biomass of average of $28.5 \mathrm{ppm}$, which is expected for coal and biomass based fuels. The combined effects of the low share mixed fuel (i.e. CCP:El-cerrejon coal, 20:80 \%,wt) showed that $\mathrm{SO}_{2}$ concentration dropped to an average of $220.1 \mathrm{ppm}$. For the high share mixed fuel (i.e. CCP:El-cerrejon coal, 80:20\%, wt), the average $\mathrm{SO}_{2}$ was $152 \mathrm{ppm}$ which indicates the significance of co-firing on $\mathrm{SO}_{2}$ emissions. NOx ( $\mathrm{NO}$ and $\mathrm{NO}_{2}$ ) concentrations show averages of $231.1,479.5,479.3 \mathrm{ppm}$, whereas the $\mathrm{N}_{2} \mathrm{O}$ emissions 
were $25.8,8.7,5.4 \mathrm{ppm}$ for El-cerrejon coal, CCP biomass and the mixed fuel (CCP:El-cerrejon coal, 80:20 $\%$, wt), respectively. The NOx concentrations of the intermediate mixed fuel (i.e. CCP 20, 40 and $60 \%$, wt) all had averages of $\sim 400 \mathrm{ppm}$. This suggests that the major source of NOx in flue gas is from fuel-N [4, 5], which explains the similar outcome between CCP (100 $\%$, wt) and high biomass mixed fuel (i.e. CCP of $80 \%$, wt). Leckner and Karlsson, 1993 [6] also indicated that NOx formation is dependence on the $\mathrm{N}$ content of the wood from combustion of wood and coal mixtures. Other possible reasons are that biomass produces greater volatile yields than coals and this can create larger fuel rich regions in the burner region, which are able to enhance the performance of low NOx burners [4]. The $\mathrm{HCl}$ had averages of 79.8, 58.6, 111.2, 108.4, 90.1, 77.2 ppm for $100 \%$ El-cerrejon coal, $100 \% \mathrm{CCP}$ and the mixed fuels $20 \% \mathrm{CCP}, 40 \% \mathrm{CCP}, 60 \% \mathrm{CCP}, 80 \% \mathrm{CCP}$, respectively; indicated higher $\mathrm{HCl}$ released in low share biomass coal combustions.
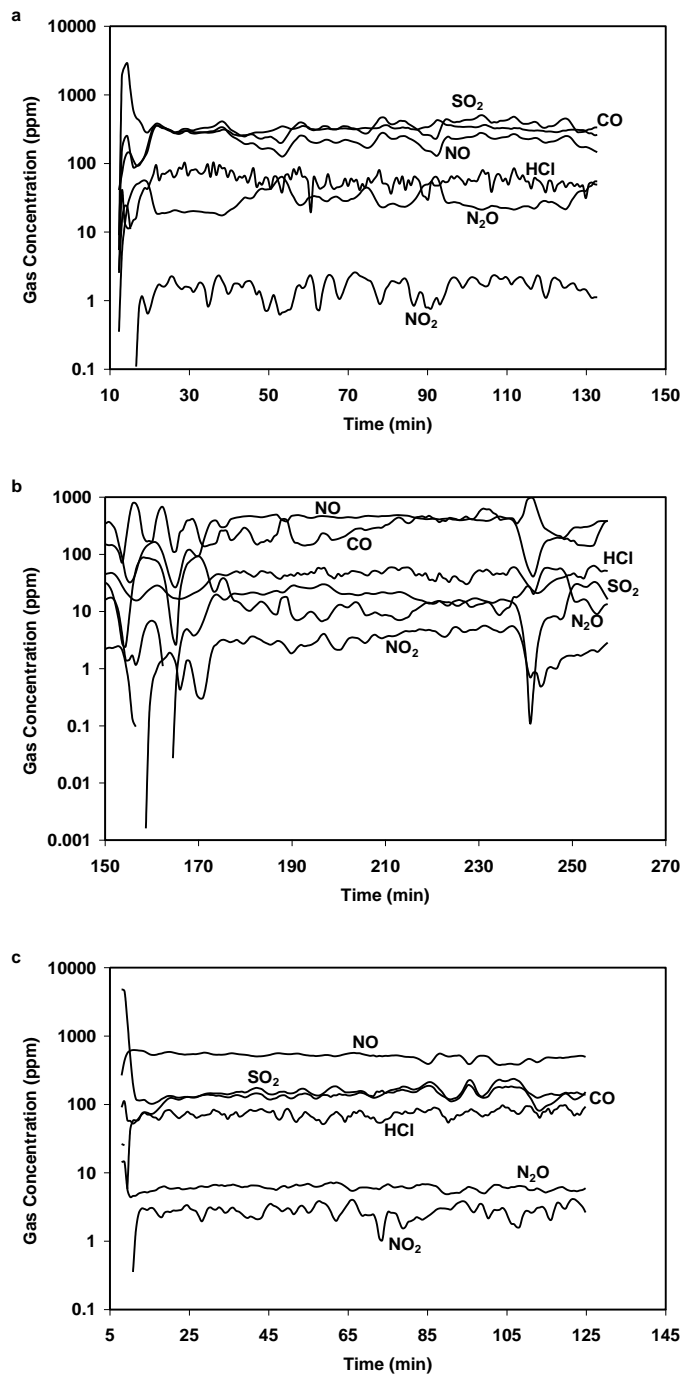

Fig. 4. Minor species emissions from combustion of a) Elcerrejon coal $(100 \%, w t), b)$ CCP $(100 \%$, wt) and c) CCP:Elcerrejon $(80: 20 \%, \mathrm{wt})$.

It is obvious that the minor gaseous species emissions (Fig. 4) remained almost constant during combustion runs and no significant drops or drastic increases have been noted (except for the case of feeding stopping due to blockage of dirt/stones in the fuels (e.g. 1 min. blockage during CCP (100\%, wt) run (Fig. 4. b)).

\section{B. Rate of deposition of the fuels combustion}

Deposits from the ceramic sections of the three deposition probes with surface temperatures of $700{ }^{\circ} \mathrm{C}$ (probe 1), $600{ }^{\circ} \mathrm{C}$ (probe 2) and $500{ }^{\circ} \mathrm{C}$ (probe 3 ) were collected after pulverised combustions runs. The ceramic section of the probe was divided into three areas which represented upstream, side-stream and downstream of the deposit build up (named as top, side and bottom deposits in this work). Figure 5 shows the deposition fluxes formed on each of the three probes for three of the fuel mixtures. This showed that the highest depositions formed at surface temperature of $500{ }^{\circ} \mathrm{C}$ (probe 3) for combustion CCP (100\%, wt) and the co-firing mixed fuel (CCP:El-cerrejon coal, 80:20\%,wt).

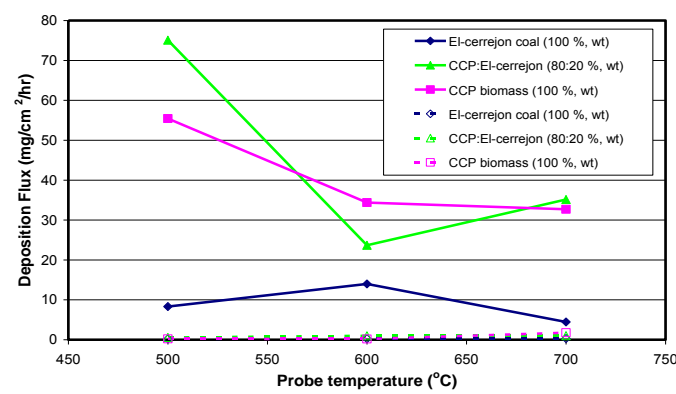

Fig. 5. Deposition rate on the surface temperatures of the three probes (on each side) for three of the fuels mixtures.

Figure 6 illustrates the deposition fluxes of all selected fuels from probe 3 , given as mass of deposits per square centimetre of surface area of the probe side per hour of feed. The results revealed higher deposition fluxes with higher shares of biomass in the fuel blend. This agrees with Gogebakan et al., 2009 [7]. Co-firing mixed fuel (CCP:El-cerrejon coal, 80:20\%,wt) exhibits the highest upstream deposit formation compared with the other fuel mixtures (with a deposition flux of $75.0 \mathrm{mg} / \mathrm{cm}^{2} / \mathrm{hr}$ ), in particular to CCP biomass (100\%, wt) of a deposition flux of $55.4 \mathrm{mg} / \mathrm{cm}^{2} / \mathrm{hr}$. This making it obvious that the different species in the mixed fuel interact with one another. Also, it can be seen that, little deposit is formed (below $1.0 \mathrm{mg} / \mathrm{cm}^{2} / \mathrm{hr}$ ) on side of the probes and none on the bottom of the probes for all the selected fuels.

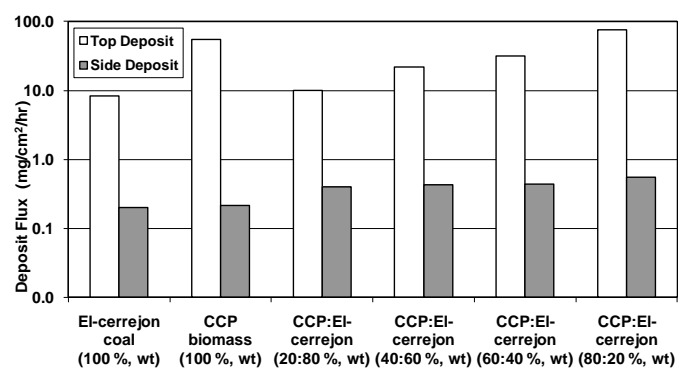

Fig. 6. Deposition rate of the probe 3 (top and side deposits) from pulverised fuels combustion 
The appearance of the deposits (on probe 3 ) after 3 hours and 30 minutes, 3 hours and 10 minutes of feed CCP biomass $(100 \%, \mathrm{wt})$ and mixed fuel (CCP:El-cerrejon, $80: 20 \%$, wt), respectively, are shown in Figure 7. This shows that the deposits were coarse with less fibrous and more porous texture for co-firing this mixed fuel when compared to $100 \% \mathrm{CCP}$. Indications from these photographs were in line with observations by SEM analysis. Also, it can be seen from the SEM images that the deposit particles are much larger for CCP $(100 \%$, wt $)$ and mixed fuel (CCP:El-cerrejon coal, 80:20\%, wt) combustion (seen in Figure 8) when compared to $100 \%$ El-cerrejon coal and low ratio of mixed biomass fuel of $20 \%$ CCP (seen in Figure 9).

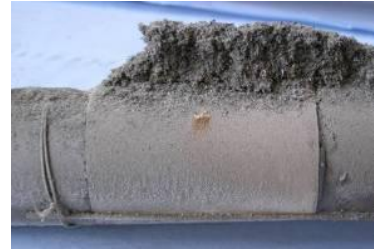

(a)

Fig. 7. Close up view of the deposits formed (top \& side) on probe $3\left(500{ }^{\circ} \mathrm{C}\right)$ from a) CCP $(100 \%$, wt) and b) CCP:Elcerrejon $(80: 20 \%, w t)$ combustion.

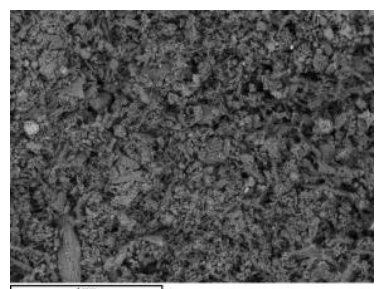

(a)

Fig. 8. SEM images of the top deposits formed on probe $3(500$ $\left.{ }^{\circ} \mathrm{C}\right)$ from a) CCP $(100 \%$, wt) and b) CCP:El-cerrejon $(80: 20 \%$, wt) combustion.

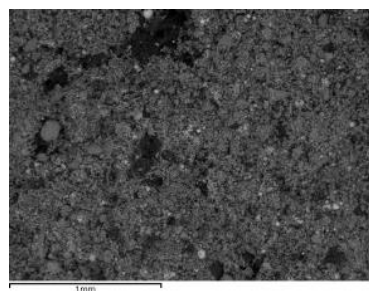

(a)

Fig. 9. SEM images of the top deposits formed on probe 3 (500

${ }^{\circ} \mathrm{C}$ ) from a) El-cerrejon coal $(100 \%$, wt) and b) CCP:Elcerrejon $(20: 80 \%$,wt) combustion.

The elemental compositions of the deposits formed on the tops and sides of all three probes for combustion Elcerrejon coal $(100 \%$, wt), CCP (100\%, wt) and high ratio biomass co-firing mixed fuel (CCP:El-cerrejon coal, 80:20\%,wt) analysed by EDX are shown in Figure 10.

Inspection of the figure reveals varying concentrations of silicon, calcium, sulphur, potassium, iron and aluminium in the deposits of all probes. Silicon and aluminium combined are coal derived with high melting point compounds that can tie up alkalis. High concentrations of potassium and sulphur suggest formation of potassium sulphates in the deposits. Potassium concentration in the deposits of probe 3 (side ash) is found to be higher than potassium content in the other probe deposits with 23.2, 23.1, $23.6 \%$ moles of El-cerrejon coal (100\%,wt), CCP biomass (100\%, wt) and CCP:El-cerrejon coal (80:20\%, $\mathrm{wt})$, respectively. Sulphur concentrations behaved in a similar way (i.e. high concentration on probe 3 ) with concentrations of $7.1 \%$ moles of El-cerrejon coal and CCP biomass tests, except CCP:El-cerrejon fuel mixtures which resulted in a higher sulphur concentration on probe 1 with $11.3 \%$ moles. On the other hand, chlorine concentrations are formed in all probes of $100 \% \mathrm{CCP}$ biomass test (as expected) and none for El-cerrejon coal. Whereas, the deposits for the mixed fuel (CCP:Elcerrejon coal, 80:20\%, wt) showed chlorine formed only in the side deposits of probe 2 and probe 3 with concentrations of 5.5 and $4.0 \%$ moles, respectively. Potassium and chlorine in the deposits form potassium chloride which is a highly fouling compound leading to corrosion of boiler components $[8,9]$. The appearance of $\mathrm{KCl}$ in the deposit was confirmed by XRD results. These findings show that the $\mathrm{Cl}$ content of the deposits formed from the CCP:El-cerrejon coal $(80: 20 \%$, wt) $\operatorname{mix}$ is intermediate between the behaviour of the two pure fuels.
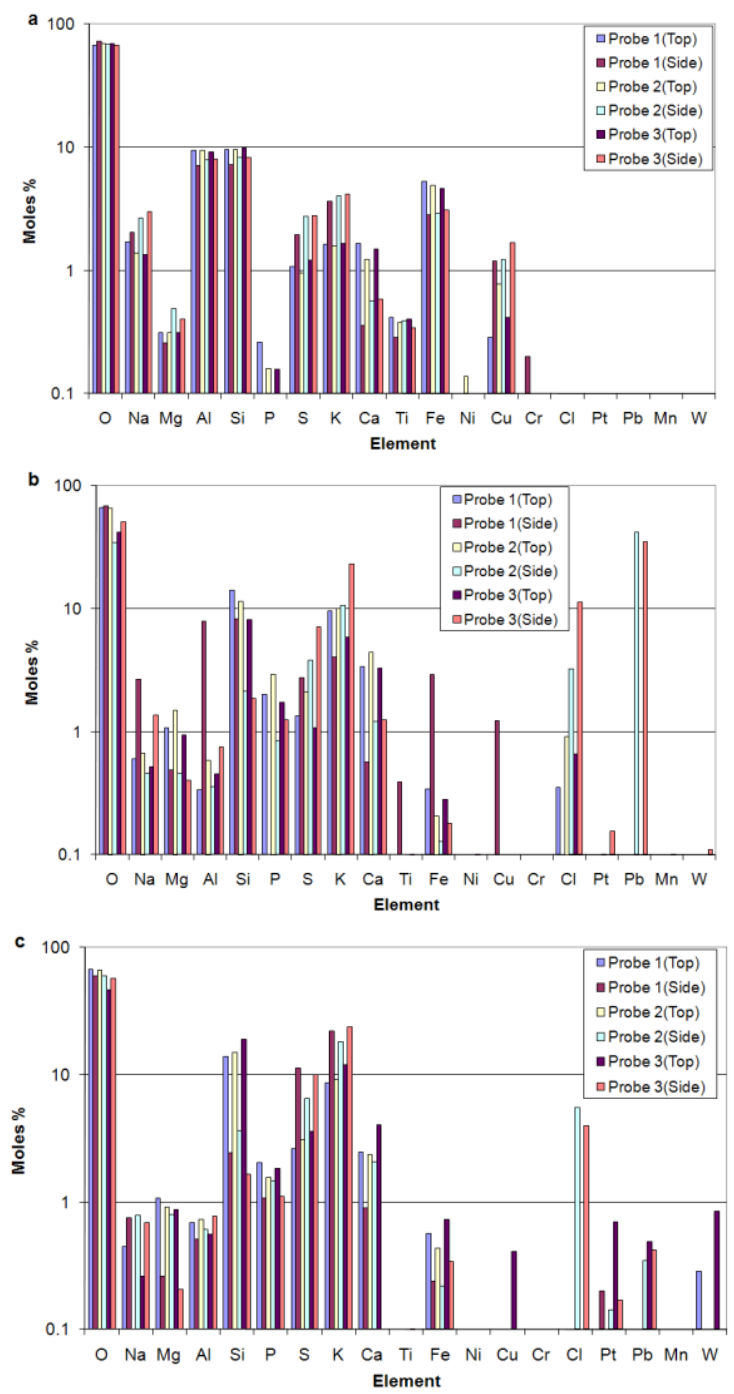

Fig. 10. Elemental concentrations of the three probe deposits from a) El-cerrejon coal (100\%,wt), b) CCP (100\%,wt) and c) CCP:El-cerrejon (80:20\%, wt). 
Co-firing mixed fuels $20 \%, 40 \%, 60 \%$ CCP with coal showed a linear increase of $\mathrm{Cl}$ in side deposit of probe 3 $\left(500{ }^{\circ} \mathrm{C}\right)$ with a concentration of $0.1,0.4$ and $1.9 \%$ moles, respectively (seen in Figure 11). Also, $60 \%$ CCP tests showed chlorine formation in the side deposit of probe $2\left(600{ }^{\circ} \mathrm{C}\right)$ with concentrations of $4.6 \%$ moles. This outcome explains the fact pointed out earlier that $\mathrm{HCl}$ concentrations were higher in combustion gases of low share biomass with coal. This has been noticed by Bartolome et al., 2009 [10] with no chlorine content in the deposit samples studied and suggested that the majority of the $\mathrm{Cl}$ was released as $\mathrm{HCl}$ gas when burning cynara biomass with coal (at shares of $15 \%$ ).
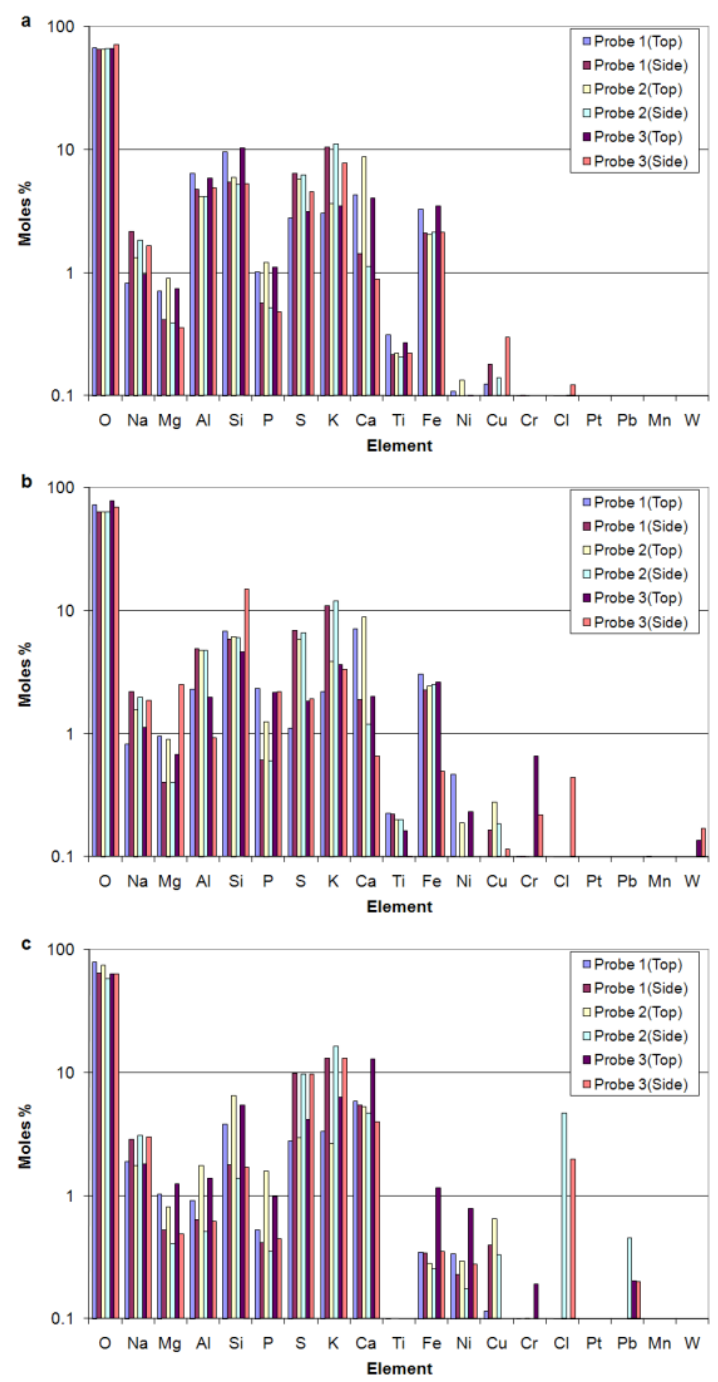

Fig. 11. Elemental concentrations of the three probe deposits from a) CCP:El-cerrejon (20:80 \%,wt), b) CCP:El-cerrejon $(40: 60 \%, w t)$, and c) CCP:El-cerrejon (60:40\%, wt).

\section{Conclusion}

Co-firing of cereal co-product (CCP) biomass with coal was carried out in a pilot-scale PF combustor test rig in order to ascertain the effect of increasing the biomass percentage on the fouling propensity and combustion performance. Flue gas emissions and ash deposition were the two main issues addressed in this work as these are important in the area of combustion of biomass for power generation.

The results show no operational/feeding problems and high combustion efficiency for all fuel mixes. The emissions of $\mathrm{SO}_{2}$ have reduced with increasing the share of CCP. The gas temperature around the deposit probes was maintained relatively constant in the range 800-900 ${ }^{\circ} \mathrm{C}$. The deposition flux was found to increase with increasing levels of CCP. SEM-EDX showed that K and $\mathrm{S}$ concentrations on the deposition probes with surface temperature of $500{ }^{\circ} \mathrm{C}$ were higher than on other probes. $\mathrm{Cl}$ was formed on all probes from $100 \% \mathrm{CCP}$ tests but only formed on the lower temperature probes when using the other fuels mixes. The $\mathrm{Cl}$ contents of these deposits increased with increasing levels of CCP.

\section{Acknowledgement}

The authors gratefully acknowledge the UK Engineering and Physical Sciences Research Council (EPSRC) via the Sustainable Power Generation and Supply (SUPERGEN) "Bio-energy" consortium and SUPERGEN "Plant Life Extension" consortium, as well as the UKTSB under project no. W0639C for the financial support provided.

\section{References}

[1] Department for Business Enterprise and Regulatory Reform, (BERR), UK Energy in Brief: A national Statistics Publication, (2007), (available at: http://www. berr.gov.uk/files/file39881.pdf).

[2] K.R.G. Hein and J. M. Bemtgen, "EU clean coal technology, co-combustion of coal and biomass", Fuel Process Technology 1998, Vol. 54, pp. 159-169.

[3] J. Hansson, G. Berndes, F. Johnsson and J. Kjarstad, "Cofiring biomass with coal for electricity generation-An assessment of the potential in EU27”, Energy Policy 2009 Vol. 37, pp. 1444-1455.

[4] S. Van Loo and J. Koppejan, The Handbook of Biomass Combustion and Co-firing, Earthscan Publisher, London, UK (2008).

[5] D.O. Hall and R.P. Overend, "Biomass Regenerable Energy”, John Wiley \& Sons Ltd. Chichester, UK (1987).

[6] B. Leckner and M. Karlsson, "Gaseous emissions from circulating fluidised bed combustion of wood", Biomass and Bioenergy 1993, Vol. 4, pp. 379-389.

[7] Z. Gogebakan, Y. Gogebakan, N. Selcuk and E. Selcuk, "Investigation of ash deposition in a pilot-scale fluidised bed combustor co-firing with lignite", Bioresource Technology 2009, Vol. 100, pp. 1033-1036.

[8] M. Montgomery and O.H. Larsen, "Field test corrosion experiments in Denmark with biomass fuels, Part 2: Cofiring of straw and coal", Materials and Corrosion 2002, Vol. 53, pp. 185-194.

[9] I. Obernberger, F. Biedermann, W. Widmann and R. Riedle, "Concentrations of inorganic elements in biomass fuels and recovery in the different ash fractions" Biomass and Energy 1997, Vol. 12, pp. 211-224.

[10] C. Bartolome, I. Ramos and A. Gil, "Ash deposition in cofiring using cynara biomass residues with coal in a PF pilot plant", in Proceedings of the $17^{\text {th }}$ European Biomass Conference and Exhibition 2009, Hamburg, Germany, pp.1230-1237. 